Journal of Social Sciences 6 (3): 488-497, 2010

ISSN 1549-3652

(C) 2010 Science Publications

\title{
The Emerging Consumer Culture in Bangladesh: Everyday Life and Festivals in Rural Areas
}

\author{
Md. Motaher Hossain \\ Department of Economics and Management, \\ University of Helsinki, P.O. Box 27, 00014, Finland
}

\begin{abstract}
Problem statement: Bangladesh, often better known to the outside world as a country of natural calamities, is a poor and low-income country. Bangladesh's main challenge is to reduce poverty through increasing equitable income. Although Bangladesh has faced many problems since its independence in 1971, its gross domestic product has been growing steadily and the country has achieved much success in social indicators. This article explores the culture of consumption in rural Bangladesh and answers the following question: How is Bangladeshi culture associated with consumption. Approach: This study employed a triangulation of methods: namely semi-structured indepth qualitative interviews, ethnography and unstructured conversations substantiated by secondary sources and photographs. Results: This study highlighted consumption and other related issues of marriage and dowry, household decision making, division of labor, as well as different festivals such as Eid (for Muslims), the Bengali New Year and Durga puja (for Hindus). Early marriage and dowry are still practiced in rural areas. Women in rural Bangladesh perform most of the household work but men, as in any other patriarchal society, make the major decisions. Conclusion: The government and NGOs should engage in various activities to boost awareness among the rural people.
\end{abstract}

Key words: Cultural consumption, festivals, marriage and dowry, decision-making, division of labor

\section{INTRODUCTION}

Bangladesh, once known as 'Sonar Bangla' (Golden Bengal), has a long and glorious cultural heritage. 'Its long, turbulent history is replete with the epic saga of invasions and subjugation that resulted in a great deal of cultural fusion and transfusion' (Shrestha, 2002). Bangladesh was ruled by Buddhists and Hindus for much of its history. From 1202-1757, Bangladesh was under the rule of the Muslims, who came from West Asia and broke the long chain of Buddhist and Hindu rule (Ahmed, 2004). Following Muslim rule, Bangladesh fell under British rule for about two centuries from 1757-1947. Initially called East Pakistan, Bangladesh was a part of Pakistan from 19471971, the year it achieved its independence. Consequently, the indigenous culture of Bangladesh was enriched as 'each ruling body added elements of its culture' (Shrestha, 2002).

Culture is very much associated with consumption. Dholakia and Firat (1998) argued that 'the concepts of culture of consumption, consumer culture and culture as consumption are now moving to the very centre of many social discourses'. Considering lifestyles, popular culture and self-representation, Appadurai (1996) examined the present era of globalization and provided fresh ways of viewing popular consumption patterns and debates about multiculturalism. Lury (1996) defined material culture as the name of the study of person-thing relationships where people relate to each other socially through the mediation of things. She also argued that material and culture are always combined in specific relationships and that "consumer culture is a particular form of material culture that has emerged in Euro-American societies during the second half of the twentieth century' (Lury, 1996). The study of consumer culture is assumed to be the study of 'texts and textuality', 'individual choice and consciousness' and 'wants and desires' in the context of social relations, structures, institutions and systems (Slater, 1999). Bourdieu (1987), in his classic work on cultural consumption, mentioned 'distinction', 'taste' for 'cultural goods', 'cultural capital' and 'habitus'. Referring to Bennett et al. (1999); Smith (1994) and Lizardo and Skiles (2008) argued that cultural tastes develop during one's early years as a consumer and remain largely stable afterwards. 'We all consume, but we all do it differently and certainly we think of it differently' (Sassatelli, 2007). Cronin (2002) argued that the commodity 'transforms social and economic relations, embodies and circulates material privilege and inequality and focuses ideals of social change'. 


\section{J. Social Sci., 6 (3): 488-497, 2010}

Gabriel and Lang (1995) advocate that consumption 'permeates our social relations, perceptions and images'. Thus, consumption has many faces and is studied differently in different disciplines. This study explores the cultural aspect of consumption, or cultural consumption, in rural Bangladesh by studying social relations and material constructs of life. This is a study about the practices, discourses and institutions which characterize consumer culture.

\section{MATERIALS AND METHODS}

This study used a triangulation of methods: Semistructured in-depth qualitative interviews, ethnography and unstructured conversations substantiated by secondary sources and photographs. Interviews were conducted in a rural Bangladeshi village in 2008. To compare the pre-independence and post-independence periods, people of two generations (one born before and the other born after 1971, the year Bangladesh achieved independence) were interviewed. As with Hossain (2010a; 2010b), this study also took into consideration Thompson (2000) schematic outline interviewer's guide for a flexible life-story interview in preparing the questionnaire and in conducting interviews with the respondents. This study used an in-depth analysis of the stories (interview) of a few families rather than of a large representative sample (Heyman, 1993); a total of 15 men and 7 women were interviewed with a semistructured questionnaire. Attempts were made in vain to include as many women as possible in the sample in order to maintain a male-female ratio of one. Although most households are engaged in agriculture, women are often considered housewives rather than farmers, because they do not work in agriculture full-time.

Random sampling was unsuitable for many reasons. Random sampling risked precluding the establishment of close relationships with the respondents by creating the impression that this was an official government study and that participants had to be interviewed if their household was chosen as part of the sample (Finnis, 2007). In addition, because the majority of the population works in agriculture, random sampling would have made it impossible to include participants from as many professions as possible. Many of the villagers nevertheless declined to participate in the interviews due to their heavy workload and for various other reasons (Hossain, 2010a). Respondents were therefore selected opportunistically from various occupations usually available in the villages of Bangladesh: such occupations include teachers (primary school, high school and college), farmers (who have their own land and those who do not have their own land, but work on others' land in return for a share of the crops), day laborers (who work for wages), shopkeepers, housewives and the chairman of the Union Council (Hossain, 2010b). The interviews lasted for about 1.52.5 h. Festivals, such as Eid, Durga puja and the Bengali New Year were taken into consideration. Moreover, some questions were asked in order to elicit information about the interviewee's spouse and about any unpaid labor in the households; such information would provide an idea of the division of labor in the household. Other questions enquired about the household's material possessions and how the items were acquired (e.g., prices, credit arrangements, gifts, marriage and dowry). This study also involved ethnography: the prolonged observation of the day-today lives of the respondents. Observation in meeting places such as tea stalls and haats (village centers for buying and selling that operate two or three times a week) helped to add 'a depth of understanding that would otherwise have been missing' (Finnis, 2007). The data were analyzed qualitatively and the findings were supplemented with photographs; wherever possible, the findings were also verified and compared with information from various secondary sources.

\section{RESULTS AND DISCUSSION}

The basic social unit in Bangladesh is the paribar (family), where several members live together in a bari (homestead). A samaj (society) is comprised of the members of several baris. Marriage is an important event in Bangladeshi societies. No formal caste systems exist among Muslims and for the Hindus the caste system is less rigid than in India. Social class distinctions are mainly functional, based on economic status and social standing (Shrestha, 2002). Paribar and kinship are the two main bases of social life in rural Bangladesh. Rural people live in large extended families, till all the land they own and also raise some livestock. The number of children per couple (husband and wife) has decreased over time. Respondents have fewer children than their parents and their parents had fewer children than their grandparents. The total fertility rate (the average number of children per woman) declined from 6.3 children in 1971-1975 to 2.7 children in 2007 (NIPORT., 2007). Thus average household size has decreased from 5.83 persons in 1973-74 to 4.85 persons in 2005 (Bangladesh Bureau of Statistics, 1978; 2007).

The results of this study are presented and discussed under the following subheadings: festivals, marriage and dowry, household decision-making, 
relationships between and among people, division of labor and leisure and media consumption.

Festivals: The people of Bangladesh are simple and enjoy festivity. Because most Bangladeshis are Muslim, the main festival in Bangladesh is Eid. There are two Eids every year: Eid-ul-Fitr and Eid-ul-Azha. After the fasting month of holy Ramadan comes Eid-ul-Fitr. In practice, however, the festivity of Eid-ul-Fitr begins from the first day of Ramadan, when people begin preparing for the festivity by shopping, cleaning, planning to move to the villages and so on. Eid also holds particular importance from the point of view of consumption, since to meet their religious obligations, most Muslims offer Zakat (alms comprising a certain percentage of their wealth) to the poor during Ramadan and Fitra (a small, fixed amount per household member) on or before Eid. On the other hand, Eid-ul Azha-popularly known as Kurbanir Eid in Bangladeshfalls on the 10th day of the month of Zul-Hajja (or Dhu al-Hijjah) of the lunar Islamic calendar. Muslims sacrifice animals and distribute one-third of the meat of the sacrificed animal among the poor, another third to their relatives and keep the rest for themselves. On Eid days (at least on Eid-ul-Fitr), most rural Muslims wear new clothes, prepare improved traditional foods and share the joys of this festival with their neighbors and friends. Sometimes non-Muslims also participate in the Eid festival by accepting invitations from their Muslim friends, neighbors and colleagues. One of the respondents describes how she passes Eid day:

On Eid day I get up before sunrise and begin preparing sweet-meats. After the morning prayer, we take a bath and put on new clothes. We eat those sweet-meats for breakfast. I prepare my children and husband for Eid namaj (congregational prayer). Returning from the prayer, I cook delicious foods. We have lunch and rest. In the afternoon and sometimes in the morning after the congregational prayer, I visit neighbors or friends and exchange greetings. Others also come visit me. [Interviewee 17; House wife, 49 years old]

Eid helps uphold family and social bonds in the country. Most Muslims leave urban areas and head to villages to celebrate Eid with their kin. The main rush begins the week before Eid. Unfortunately, the transportation infrastructure cannot support such mass movement over such a short period of time. Consequently, people travel on the roofs of trains, buses and launches, ignoring (or accepting) the risk to their lives (Fig. 1). Every year several accidents take place before and during Eid.

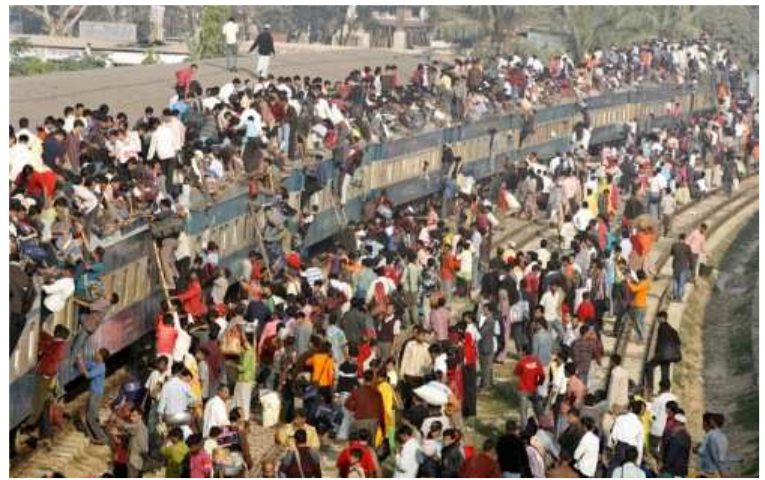

Fig. 1: Going home for Eid (Dhaka, Bangladesh). Source: Adapted from http://asqfish.wordpress.com/2008/12/14/goinghome-for-eid/ (accessed 25 Feb. 2010)

Rural people organize Eid fairs and friendly sports competitions. Electronic and print media play an active role in the festivity by broadcasting many attractive programmes, releasing new Bangla movies, publishing special issues with novels, stories and poems, Eid fashions and so on. The impact of Eid on the whole nation is incomparable; it increases consumption, generates employment, maintains social and family bonds, contributes to uphold social harmony and helps create congenial relations between the rich and poor.

Durga puja is an annual Hindu festival in South Asia that celebrates the worship of the Hindu goddess Durga. Durga puja is the year's largest Hindu festival, widely celebrated in the autumn by Hindus, the second largest religious group in the country by number. The last day of the celebration is a government holiday in Bangladesh. Among other festivals, the Bengali New Year is not celebrated widely in rural areas. Some rural people celebrate while new crops (mainly rice) are brought into their houses.

Marriage and dowry: About $88 \%$ of Bangladeshis are Muslim (Bangladesh Bureau of Statistics, 2009), so almost all marriages in rural areas follow the Muslim marriage system. In addition to Muslim customs, some regional and local rituals are followed. 'The main stream of Bangladeshi culture always prefers marital sexuality and never permits premarital, extramarital and homosexuality, although rare cases of those sexual behaviors secretly exist in both rural and urban communities as well as in different sub-cultural groups' (Uddin, 2009a).Wives cannot normally express their sexual wishes and are thus the object of their husband's sexual desires (Uddin, 2009b). In rural areas, after marriage, sons generally live in their parents' household 


\section{J. Social Sci., 6 (3): 488-497, 2010}

whereas brides move into the groom's father's house and become dependent members of his family. A housewife who married at an early age describes her experience as follows:

Being a government employee, my father had to live outside the village house. While a student in secondary school, I came with my parents to our village house to celebrate Eid. My parents received many proposals for my marriage from various suitors. At one stage, my father-in-law and his brother came to visit our house. My parents asked me to go before them. I cried a lot. My mother convinced me, saying that I would not be married simply by going there. Moreover, I was educated, so what would they think of me if I did not go before them; they would say bad things and such. Then I went before them. They asked me my name, my father's name, the class in which I was studying. After a few moments, my wedding day was set without my ever seeing the groom; as my father knew the groom and that was sufficient my husband. The marriage was entirely the will and choice of the guardians of the two sides because we-the husband and wife-never saw each other before our wedding day. [Interviewee 13; Housewife, 27 years old]

Much could be drawn from the above quotation. First, marriage (when, how and whom one should marry) depends not on the will of the boy or girl, but is a decision made by the parents or guardians. Second, the feelings or opinion of the community is very important. 'What people of the society will think if I do this' is a very powerful factor. Third, marriage at a young age is evident. Fourth, the bride and groom do not choose each other, but are chosen by the guardians of the two sides. The respondent was lucky to have only three questions to answer, because in most cases many questions regarding the prospective bride's everyday life and religion are normally asked after the introduction. Parts of the bride's body (e.g., hands, legs, hair and eyes) are also checked to ensure they are healthy. The grooms must also face the questions, but their body parts are not inspected. This trend is on the wane nowadays, as the literacy rate rises. This same interviewee also expresses perhaps the most important reason behind early marriage:

The worst thing that happened in my life is that I could not complete my studies due to marriage at an early age. My parents believed that arranging my marriage would be a problem if I was not married at an early age. I feel very sad whenever I remember that I could do something better-my life could be brighter-if only I would have been allowed to continue my studies. Therefore, I want my daughter to be as educated as possible. [Interviewee 13; Housewife, 27 years old]

Early marriage is still a major problem in Bangladesh, especially in rural areas. People are afraid that marriage proposals for their daughter or sister will not come unless she is married at an early age. Consequently, the median age at which women aged 20-24 were married is only 16.4 years (NIPORT., 2007). Although an age restriction for marriage exists (the current legal age for marriage in Bangladesh is 18 for women and 21 for men) (Chowdhury, 2004), it is difficult to enforce such restrictions for many reasons. Bangladesh lacks an efficient birth registration system and unless someone lodges an official complaint, no one dares to verify the age of the bride. Moreover, because men prefer virgin brides, most parents in rural Bangladesh encourage their daughters to remain virgin and, for that reason, prefer early marriage.

Wilhite (2008) notes that, in Southern India the dowry has become an inevitable and integral part of marriage involving a significant exchange of goods, money and property. There are two different, but interrelated and overlapping words in the marriage market: joutuk (dowry) and pawn (bride-price). Normally, the bride's family gives the dowry to the groom or the groom's family, whereas the groom or groom's family gives the bride-price to the bride (Anderson, 2007). In Bangladesh, the English word 'demand' is also widely used as a synonym for joutuk. In response to questions about joutuk, the respondents mentioned that joutuk normally constitutes one or more of the following: cash, a watch, clothing, a gold ring, furnishings (e.g., pots and pans, quilts, an umbrella), a television, a radio, a bicycle, a cassette player, a motor cycle, livestock, jewellery for the bride (one or more items of gold or silver, such as a nosepin, bangles, earrings, or necklace), agricultural land, or even land for building a house. On the other hand, they added that bride-price means cash or jewellery (one or more items of gold or silver, such as a nosepin, bangles, earrings, or necklace), sweets, sari, cosmetics, footwear and so on. 'The system of dowry (joutuk or joutak) in Bangladesh is a relatively novel concept which has, in a short period of time, become a significant customary practice among Muslims, though supported neither by religious 


\section{J. Social Sci., 6 (3): 488-497, 2010}

nor state laws' (Huda, 2006). Historically, bride-price was prevalent in Bangladesh and dowry payment became a norm only after 1964 (Amin and Cain, 1997). Hindu influence, male greed and rising consumerism have variously ascribed to the practice of dowry among the Muslims of Bangladesh (Amin and Cain, 1997).

In a study at the University of Bath, Davis (2008) showed that dowry contributes to poverty for many families with daughters as most families living in rural Bangladesh still practice it. He claimed that a dowry payment amounts to, on average, more than 200 times the daily wage of a villager. The study also suggests that marriage payments, especially dowry, are the major reasons behind early marriage.

There is a strong association between the bride's age and the amount of dowry. A larger dowry is required or an older bride since age, like dark complexion, is considered a drawback. Dowry and age of marriage are at the centre of a vicious circle, which is difficult to break. Inability to arrange a dowry may delay a girl's marriage, which in turn means higher dowry demands (Huda, 2006).

Although laws exist to prevent dowry payments and early marriage by sanctioning fines and imprisonment against harmful marriage practices, the demand and supply for dowry in the marriage market preclude the elimination of such harmful practices (Amin, 2008).

Of course, examples of marriage without joutuk or pawn do exist. In many cases, no binding contract exists between the two sides of the bride and groom regarding joutuk and pawn payments. In such cases, both sides willingly provide something to the bride and groom. This practice is ideal and praised by the society, but is not without its problems. Sometimes, the absence of a contract has little bearing on the groom's family's expectations that the bride's family should pay joutuk. At the time of marriage, if the bride's family fails to meet their expectations, the bride will face mental or physical torture or both. The respondents cited many incidents of violence against women resulting in divorce or even suicide for failure to pay the contracted (or expected) amount of joutuk. As a result, the respondents claim that with or without a contract, nearly all marriages in rural areas involve joutuk payments. Joutuk is a problem irrespective of literacy and education. Sometimes, highly educated men with good earnings demand more dowry.

Household decision-making: Although women comprise about $49 \%$ of the population of Bangladesh (Bangladesh Bureau of Statistics, 2007), a traditional patriarchal society system nevertheless persists in
Bangladesh. Historically, the culture, religions and social restrictions in Bangladesh confined women mostly to the homestead where they depend on their fathers, husbands and sons for survival in various phases of the life cycle. With the rise in literacy ratesespecially female literacy-and the intervention of various governmental and non-governmental organizations, women are coming outside the homestead to participate in various income-generating activities, such as crop production, post-harvest activities, poultry rearing, the management of livestock and fisheries and so on. All these changes have improved the status of women in rural Bangladesh (Balk, 1994; 1997a; 1997b). Even so, male family members usually make the major household decisions (Hoque and Itohara, 2008).

The respondents supported the apprehension that the education of women is an important factor in household decision-making in Bangladesh. The decision-making process is more democratic in families where both the husband and wife are literate than in the households of illiterate husbands and wives. A college teacher once said that 'If the life-partner of a man is to his liking, all their decisions will be correct. We (husband and wife) discuss everything wholeheartedly and come to conclusions together' (Interviewee 1; Male, 52 years old). In cases where the husband is literate and the wife is illiterate, the husband makes all major decisions. Due to Bangladesh's long patriarchal heritage, women are generally unwilling to play an active role in decision-making; rather, they feel more comfortable playing a passive role. A female primary school teacher said, 'I rely on his (my husband's) decisions. He informs me. I feel and believe he will do what he thinks is best. He takes my logic also' (Interviewee 17; 49 years old). Although rare, some women dominate or make most household decisions, as is evident from the following quote: 'We both make decisions. If I make a decision, he does not go against it; if he makes a decision, I do not go against it. In most cases I make the decisions, but we make important decisions jointly' (Interviewee 3: Housewife, about 55 years old).

Relationships between and among people: Bangladeshis, especially those living in rural areas, tend to be simple and very hospitable to guests, doing their best to serve them. Even this author, during the interviews, was treated very well by all the respondents at their houses. Interpersonal relations are normally very good in villages. In times of need, such as during marriages, funerals and natural disasters, they readily help each other. Every family tries to give their children 


\section{J. Social Sci., 6 (3): 488-497, 2010}

some special education (within the household, not necessarily in school) related to norms and proper behavior. Juniors normally respect seniors and try to do what they say. Poor and illiterate people used to follow the instructions of the rich and influential people of the villages and sometimes used to be exploited. Things are changing now, however: "with the increase in literacy rate and economic development, most people in a village get the chance to say something. Before, only what the morol-matobbor (village heads) would say would happen; no one could say anything against their will' [Interviewee 22; Farmer (own land), about 65 years old]. The older respondents also mentioned that interpersonal relationships and respect for seniors were declining.

Division of labor: Work outside the home is for the male and household work (inside the home) is meant for women only. Men would never do any household job in a grand (combined) family. One of the female respondents describes:

We had a joint family where my grandfather, grandmother, brothers and sisters of my father, wives and children of my uncles used to live together in the same house. Men never did any household work. I did not do anything until we were in a joint family. But, when my father was separated from that family and had his own single family, I did a lot of things such as cleaning the house, bathing my brothers and sisters and serving foods. My father used to help with household work such as organizing and collecting the materials needed for cooking and serving food himself. [Interviewee 6: Female, 33 years]

It is important to note from the above quotation that men do not even serve their own food themselves; food is served by women only. Her father did no household work until they were in a joint family; normally the wife or some other women serve the food from cooking pots into different bowls and pots. She also brings plates, glasses and water. The men only eat, leaving the unclean utensils for the women to collect. The women clean the utensils, as though cooking, serving food and cleaning the utensils are meant for women only. Even if a woman works outside the home in any profession, she must still complete those tasks before leaving the home. Now, slowly, with the growing number of single families and educated individuals, men are beginning to do some household work, but women still continue to do the majority of such work. An educated respondent claimed:

My wife does all the household work, but she sometimes gets tired. Depending on the amount of time I am with her and if I get the chance, I do the work. I can prepare the bed for sleep and can keep the clothes on the shelf (dress stand) in order. Since we are lifepartners, I can do all of it for her. Although I am too busy, I also take care of our children, but she does the most because I work outside the home. If our child suffers from a fever during the night, I would not sleep the whole night and let my wife sleep. Because she is at home more, she can take care of more in the home. [Male, 52 years old]

When one's wife becomes ill, pregnant, or when she goes elsewhere, men must do household work. In this case, female relatives or neighbors help. Still, pregnant women in rural areas go to their parents' house to deliver the baby, especially if it is the woman's first child.

Leisure and media consumption: Contrasting the general conception that leisure activities involve some costs, rural Bangladeshis consider such activities leisure activities for the refreshment of the mind. They have their own ways of pursuing leisure activities, which mostly involve nature and are free of cost. A respondent described leisure as follows:

What I understand by the word Chittobinodon (leisure) is arrangements through which I can overcome fatigue when I am mentally tired with family and other matters and which, at the same time, give me pleasure. In this village setting, I watch television, listen to the radio, or go to watch a match-either football or cricket-in the local fields or talk and listen to some people in a tea stall. Perhaps I forget my tiredness for a while and find pleasure. These are my leisure activities. These activities do not incur costs or cost very little. There is no way to have paid entertainment here. Mostly we have to find pleasure from nature. Watching the World Cup while sitting in the gallery and watching a match between two para (parts) of a village are the same kind of leisure. One is expensive, but the other is free. [Interviewee 2: Male, 56 years] 
As mentioned earlier, women are often sequestered inside the four walls of the home. Their leisure activities differ from those of men. Rural Bangladeshis eat mostly foods prepared at home. Women normally do the cooking, so cooking-related work takes most of rural women's time. In the past, rural women had no free time for leisure as they used to have to wake up before sunrise and begin husking paddies for rice and grinding grain for flour, two very difficult and timeconsuming activities, as well as collect water from distant sources. Rural women now have more 'free time' and can enjoy some leisure activities such as watching TV, chatting with others, visiting neighbors or relatives and so on, since machines now husk paddies and grind grain and drinking water is readily available (Hossain, 2010b).

Football was the most popular game in Bangladesh. On the one hand, due to disappointing performances at the national and international level, popularity of football is on the wane. On the other hand, Bangladesh enjoys test cricket playing status and also plays in world cup cricket. Cricket has therefore become possibly the most popular game in Bangladesh. Bangladeshis, both rural and urban, often watch live cricket matches on television either at home or in other places (if television is unavailable at home). Any cricket match between India and Pakistan draws the most attention. Tea stalls have become an important place for recreation in rural areas. Rural men from all walks of life nowadays go to tea stalls either in the morning or in the evening or both. Farmers and others who work in the daytime gather in tea stalls in the evening. They drink tea, gossip and watch television (Fig. 2).

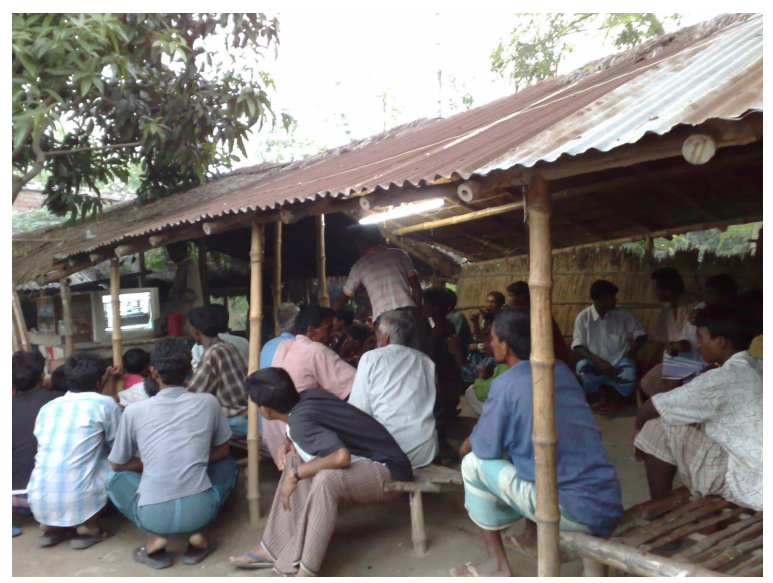

Fig. 2: Watching a cricket match between India and Pakistan on television
In reference to Kortti and Mahonen (2009) era of scarcity, availability and plenty, the era of scarcity continues in rural Bangladesh, where television is a social and cultural medium and a vehicle for discussing and sharing everyday life experiences. State-owned Bangladesh Television (BTV) began broadcasting in 1964 and, until the end of 1998, remained the sole television channel in the country. With the recently improved availability of electricity in rural areas, the decrease in the prices of television sets and the increase in income and purchasing power, the number of television watchers has grown tremendously. 'Even if one household has no television of their own, they can still watch popular programmes at their neighbor's house or in common places such as clubs, tea stalls and other shops that have a television'(Hossain, 2010b). In recent years, both the number of television channels and the duration of programmes have increased noticeably; consequently, television has emerged as the most dominant medium of popular cultural consumption and cultural entertainment in Bangladesh (Shrestha, 2002). Televisions and radios play a vital role in times of natural calamities and promote awareness among rural people of various aspects of social life.

Since 1956, the Bangladeshi film industry based in Dhaka, sometimes known as Dhallywood-a merging of the words Dhaka and Hollywood-has produced approximately 100 movies a year. In the beginning, Bengali films were very popular and could draw audiences from the Bangladeshi middle class. Sadly, Dhallywood's heyday has passed and except for a few films, the educated middle class very seldom visits its cinema halls due to the poor and unhealthy environmental conditions there as well as the 'inferior quality' of the films. Still, rural Bangladeshis enjoy watching Bengali films aired on television channelsespecially by the BTV, the only terrestrial television channel in Bangladesh-on weekends and holidays.

'Contemporary changes in the modes of production, distribution, consumption and regulation of culture related to changes in organization of media and communication systems are reconfiguring the scales, spatialities and territorialities of the cultural' (Barnett, 1999). The globalization of the media landscape of Asia, which began in the 1990s, has been most rapid worldwide in terms of the growth in satellites, transnational television channels and online networks (Kim, 2010). In Bangladesh, however, the Bollywood film culture is circulated and consumed amid a longstanding 'love-hate relationship'. Although no Bollywood films are shown in the cinema halls or theatres of Bangladesh due to a ban imposed by the 
Pakistani government in 1965 (Bangladesh was a part of Pakistan known as East Pakistan), Bollywood is nevertheless omnipresent as a popular culture in many ways (Raju, 2008).

Most Bangladeshis living in small towns or even villages also watch Bollywood films, film trailers and film songs on various transnational television channels ranging from Bollywood for You (B4U) to MTV India. Bollywood films and film songs entertain passengers in long-haul public transport vehicles (e.g., intercity coaches and steamers). Mobile companies offer Bollywood film songs as ringtones and young people listen to the songs on their walkmans. Such songs also blare from horn speakers, radio sets and audio players in shopping complexes, at family gatherings such as weddings and puberty rites, as well as at religious and social festivals in the cities and villages. [...] Numerous local film magazines, mostly in Bengali, carry the latest upheavals in the personal and professional lives of Bollywood stars. All the serious dailies and weeklies also devote one or more sections to the gossip and news of the Bollywood film industry. Posters, postcards, notebooks, writing pads (used by school students), calendars, albums-all bearing pictures of Bollywood film stars-are also available on every street corner in contemporary Bangladesh. The walls in college and university dormitories are normally covered with posters of Bollywood stars (Raju, 2008)

The above quotation clearly shows that Bollywood cinema is a very popular means of entertainment that has influenced cultural media consumption in Bangladesh. Televisions, VCRs and DVD players have influenced the consumption patterns of rural people (Hossain, 2010b) and made the household consumption of Bollywood films and songs much easier in the absence of theatrical viewing options. Following the fashions of one's favorite stars is also common among Bangladeshi youth. Although Bollywood films are very popular, many feel this trend undermines Muslim and Bengali culture when, in fact, they should uphold it. But the effect of globalization and transcultural consumption is causing people to negotiate with their national, cultural and religious identities and this view is waning in practice.

\section{CONCLUSION}

Finding any significant studies on the cultural aspects of consumption or how consumption is associated with rural Bangladeshi culture is difficult. This study attempted to focus on cultural aspects of consumption. Early marriage and dowry are still practiced in rural areas despite legal bans. Older brides require larger dowries, which makes it extremely difficult to break the vicious circle of marriage at an early age. Women in rural Bangladesh perform most of the household work; men very seldom help women in this regard, as though household work were for women only. Men, as in any other patriarchal society, make the major decisions and women simply work to implement that decision. Laws against early marriage and dowry payments are simply insufficient to eradicate the curse of the dowry. The government and NGOs must engage in various activities to boost awareness among the rural people. Education could be the primary solution to these problems, as research has shown that educated men more often discuss matters with their wives before making important decisions and offer to help their wives with the household work; moreover, many educated men demand no dowry. Effective birth registration systems and verification of age at marriage could be additional initiatives to discourage early marriage.

\section{ACKNOWLEDGEMENT}

The author is grateful to Professor Visa Heinonen for his valuable comments, suggestions and kind help; to the Department of Economics and Management of the University of Helsinki for providing the facilities for this study and to the Jenny and Antti Wihuri foundation for (partly) financing this study.

\section{REFERENCES}

Ahmed, S., 2004. Bangladesh: Past and Present. 1st Edn., APH Publishing Corporation, New Delhi, ISBN: 10: 8176484695, pp: 390.

Amin, S., 2008. Reforming marriage practices in Bangladesh. Population Council, Inc. http://www.popcouncil.org/pdfs/TABriefs/PGY_Br ief31_MarriageBangladesh.pdf

Amin, S. and M. Cain, 1997. The Rise of Dowry in Bangladesh. In: The Continuing Demographic Transition, Jones, G.W., R.M. Douglas, J.C. Caldwell and R.M. D'souza (Eds.). Oxford University Press, New York, ISBN: 10: 0198292570, pp: 290-306. 
Anderson, S., 2007. The economics of dowry and bride price. J. Econ. Perspect., 21: 151-174. http://www.jstor.org/stable/30033756

Appadurai, A., 1996. Modernity at Large: Cultural Dimensions of Globalization. 1st Edn., University of Minnesota Press, Minneapolis, ISBN: 10: 0816627932, pp: 248.

Balk, D., 1994. Individual and community aspects of women's status and fertility in rural Bangladesh. Popul. $\quad$ Stud., 48 21-45. http://www.jstor.org/stable/2174957

Balk, D., 1997a. Change comes slowly for women in rural Bangladesh. Asia-Pac. Popul. Policy, 41: 1-4. PMID: 12346527

Balk, D., 1997b. Defying gender norms in rural Bangladesh: A social demographic analysis. Popul. Stud., 51: 153-172. http://www.jstor.org/stable/2174683

Bangladesh Bureau of Statistics, 1978. A report on the household expenditure survey 1973-75. Ministry of Planning.

Bangladesh Bureau of Statistics, 2007. Report of the household income and expenditure survey 2005. Ministry of Planning.

Bangladesh Bureau of Statistics, 2009. Statistical pocket book of Bangladesh 2008. Ministry of Planning.

http://www.bbs.gov.bd/dataindex/pby/pk_book_08.pdf

NIPORT., 2007. Bangladesh Demographic and Health Survey 2007. National Institute of Population Research and Training. http://www.measuredhs.com/pubs/pdf/FR207/FR2 07\%5BApril-10-2009\%5D.pdf

Barnett, C., 1999. Culture, government and spatiality: Reassessing the 'Foucault effect' in cultural-policy studies. Int. J. Cult. Stud., 2: 369-397. DOI: 10.1177/136787799900200306

Bennett, T., M. Emmison and J. Frow, 1999. Accounting for Tastes: Australian Everyday Cultures. 1st Edn., Cambridge University Press, Cambridge, ISBN: 10: 0521635047, pp: 327.

Bourdieu, P., 1987. Distinction: A Social Critique of the Judgment of Taste. 1st Edn., Harvard University Press, London, ISBN: 10: 0674212770, pp: 640 .

Chowdhury, F.D., 2004. The socio-cultural context of child marriage in a Bangladeshi village. Int. J. Soc. Welfare, 13: 244-253. DOI: 10.1111/j.13696866.2004.00318.x

Cronin, A., 2002. The substance of consumption: Alchemy, addiction and the commodity. Int. J. Cult. Stud., 5: 316-335. DOI: $10.1177 / 1367877902005003570$
Davis, P., 2008. Study reveals marriage dowry as major cause of poverty in Bangladesh. University of Bath. http://www.bath.ac.uk/news/2008/10/30/povertyresearch-bangladesh.html

Dholakia, N. and A.F. Firat, 1998. Consuming People: From Political Economy to Theaters of Consumption. 1st Edn., Routledge, London, New York, ISBN: 10: 0415166802, pp: 208.

Finnis, E., 2007. The political ecology of dietary transitions: Changing production and consumption patterns in the Kolli hills, India. Agric. Hum. Values, 24: 343-353. DOI: 10.1007/s10460-0079070-4

Gabriel, Y. and T. Lang, 1995. The Unmanageable Consumer: Contemporary Consumption and its Fragmentations. 1st Edn., Sage Publications Ltd., London, ISBN: 10: 080397745X, pp: 224.

Heyman, J.M.C., 1993. Life and Labor in the Boarder: Working People of Northeastern Sonora, Mexico: 1886-1986. Americas, 49: 556-558. http://www.jstor.org/pss/1007424

Hoque, M. and Y. Itohara, 2008. Participation and decision making role of rural women in economic activities: A comparative study for members and non-members of the micro-credit organizations in Bangladesh. J. Soc. Sci., 4: 229-236. DOI: 10.3844/.2008.229.236

Hossain, M.M., 2010a. Changing consumption patterns in rural Bangladesh. Int. J. Consum. Stud., 34: 349-356. DOI: 10.1111/j.1470-6431.2010.00866.x

Hossain, M.M., 2010b. Role of technology in consumption and everyday life in rural Bangladesh. Technol. Soc., 32: 130-136. DOI: 10.1016/j.techsoc.2010.03.004

Huda, S., 2006. Dowry in Bangladesh: Compromizing women's rights. South Asia Res., 26: 249-268. DOI: 10.1177/0262728006071707

Kim, Y., 2010. Female individualization: Transnational mobility and media consumption of Asian women. Media Cult. Soc., 32: 25-43. DOI: 10.1177/0163443709350096

Kortti, J. and T.A. Mahonen, 2009. Reminiscing television: Media ethnography, oral history and Finnish Third generation media history. Eur. J. Commun., 24: 49-67. DOI: $10.1177 / 0267323108098946$

Lizardo, O. and S. Skiles, 2008. Cultural consumption in the fine and popular arts realms. Sociol. Compass, 2: 485-502. DOI: 10.1111/j.17519020.2008.00101.x

Lury, C., 1996. Consumer Culture. 1st Edn., Polity Press, Cambridge, ISBN: 10: 0745614418, pp: 280. 
Raju, Z.H., 2008. Bollywood in Bangladesh: Transcultural Consumption in Globalizing South Asia. In: Media Consumption and Everyday Life in Asia, Kim, Y. (Ed.). Routledge, New York, ISBN 10: 0415962455, pp: 155-166.

Sassatelli, R., 2007. Consumer Culture: History, Theory and Politics. 1st Edn., Sage Publications Ltd., London, ISBN: 13: 9781412911818, pp: 248.

Shrestha, N.R., 2002. Nepal and Bangladesh: A Global Studies Handbook. 1st Edn., ABC-CLIO, California, ISBN: 10: 1576072851, pp: 323.

Slater, D., 1999. Consumer Culture and Modernity. 1st Edn., Polity Press, Cambridge, ISBN: 10: 0745603041, pp: 240.

Smith, T.W., 1994. Generational differences in musical preferences. Popular Music Soc., 18: 43-59. DOI: 10.1080/03007769408591554

Thompson, P., 2000. The Voice of the Past: Oral History (Opus Books). 3rd Edn., Oxford University Press, Oxford, ISBN: 10: 0192893173, pp: 384.
Uddin, M.E., 2009a. Age at first marriage for husband and wife between Muslim and santal communities in rural Bangladesh: A cross-cultural perspective. Int. J. Hum. Soc. Sci., 3: 31-39. http://www.akademik.unsri.ac.id/download/journal /files/waset/v3-1-4-1.pdf

Uddin, M.E., 2009b. Cross-cultural comparison of marriage relationship between Muslim and Santal communities in rural Bangladesh. World Cult. J., 17: 1-17. http://escholarship.org/uc/item/0w13d105

Wilhite, H., 2008. Consumption and the Transformation of Everyday Life: A View from South India. 1st Edn., Palgrave Macmillan, New York, ISBN: 13: 9780230542549, pp: 224. 